\title{
The Role of the Struggle Against Terrorism in Tourism Development in Azerbaijan
}

\author{
VASIF ALIYEV \\ Department of Economics and Business Administration, Lecturer \\ Azerbaijan State University of Economics (UNEC) \\ Faculty of Economics of Turkish World, Baku \\ AZERBAIJAN
}

\begin{abstract}
The development of technology, the comfort of air transport and the annual reduction in prices have been the motivating factors for tourists. Despite this motivation, travelling abroad is a cause for concern. One of the biggest sources of concern is the risk of a terrorist act. The country that wants to develop tourism must take various measures to prevent these problems. Initially, literature review was conducted in this study and it revealed how the terrorist acts affect the tourism industry in Turkey. At the same time, information on prevented terrorist acts in Azerbaijan has been given for years, with statistics showing how these events affect the number of tourists. In the end, recommendations were given on what measures could be taken in the future for sustainable tourism.
\end{abstract}

Key Words: - Terrorism, tourism industry, Azerbaijan

Received: November 9, 2019. Revised: April 30, 2020. Accepted: May 12, 2020. Published: June 8, 2020

\section{Introduction}

Rapidly growing tourism under the influence of globalization has become one of the key areas of the global economy since the last half of the twentieth century. Developing vehicles, liberalized global travel, growing economies, and diversified payment methods have played a leading role in the development of tourism along with globalization. Rapid development in the tourism industry in the world has created competition among countries that want to get the most out of this area, and it is not surprising that in 2019 the number of tourists worldwide was 1.5 billion [5]. Based on current trends, economic prospects and the UNWTO Confidence Index, UNWTO forecasts a growth of $3 \%$ to $4 \%$ in international tourist arrivals worldwide in 2020. Looking at the information presented above, the worldwide commercialization of tourism is remarkable. Tourism provides commercial benefits not only to its own area, but also to other industries and services. Along with all these, not only material comfort, but also psychological comfort for tourists is important. Countries providing tourism services for psychological comfort should take action against epidemics, natural disasters, war and terrorism.

Tourism has been an area of creating a competitive environment among countries with the potential for tourism because it generates huge amount of income. Tourism also plays an important role in the economies of the countries due to the inflow of foreign currency into the country and national income, increasing employee engagement and the impact on areas besides tourism. As in many countries, our country has been targeted to terrorism acts from time to time. It is useful to examine the relationship between tourism and terrorism from both sides, namely, the prevention of terrorism acts and the impact of tourism on various aspects. Below, these topics will be explored under different headings and will focus on what measures should be taken to reduce terrorist acts in tourist destinations. The recent terrorist acts have also directly or indirectly affected the tourism sector, which is an important part of the global economy. Many countries, including Azerbaijan, are still under the threat of terrorism. The tourism industry and the economy are severely damaged by the terrorist attacks that have killed many innocent people. For this reason, terrorist attacks and the concept of terrorism; remains as one of the most determining considerations that adversely affects tourism.

\section{An overview of literary works}

Many empirical analyses in sources on tourism and terrorism are obtainable in the literature. Some of these studies are directly related to European countries, some to developing countries, some to Middle East countries, and some studies to all country groups comparatively. When we look at the economic sources, we see that there are numerous studies examining the effects of national and international terrorist acts on tourism. Almost all theoretical and practical studies have shown that demand in tourism and revenue have decreased due 
to the increase in terrorist acts. For the country where acts of terrorism are committed, the tourism potential has diminished and the economic system as a whole has been destroyed.

A study by Akinci and Yilmaz (2015) examined the relationship between terrorism and tourism for a total of 143 countries, with 45 developed, 73 developing and 25 least developed, taking into account the period of 2002-2011. As a result of the study, the Model prediction results revealed that international terrorism has a negative impact on various criteria that measure the potential of tourism. Forecast findings confirming Granger causality analysis show that frequent acts of terrorism in developing and least developed countries have been detrimental for travel costs, the number of tourists arriving and tourism revenues[2].

Acar and Cetin's (2018) research in Turkey was aimed at investigating the direct relationship between terrorist incidents and tourism revenues and the impact of terrorism on tourism revenues. In the model, both short term regression analysis, as well as the long term co-integration and causality tests uncovered the effect of the terror index variance on tourism income. In other words, it has been shown that terrorist events have a negative impact on tourism revenues.

Terrorist acts in Turkey in 2005 and 2006 targeted the main tourism sector, with a decline in the total count of tourists and tourism revenues. A surge of $20.4 \%$ in cumulative total of tourists in 2005 resulted in a $6.2 \%$ decrease in 2006 . However, there was $8.5 \%$ decline in tourism revenues. As a result of the explosion by the terrorist organization in Antalya alone, the daily loss in Antalya was \$ 903,000 and up to $40 \%$ of reservations were canceled [6].

\section{Research method}

The reports of the Department of State Publication Bureau of Counterterrorism were used for the prevented terrorist attacks in Azerbaijan in 2016-2018, and the State Statistics Committee of the Republic of Azerbaijan for the number of tourists visiting Azerbaijan in 2016-2019. Local and foreign sources were used while writing the article.

\section{Definition of terror and terrorism}

Although the concepts of terror and terrorism are frequently encountered in the international arena, there is no consensus in the definition of these concepts. The words "terror" and "terrorist" in Latin have the meanings "subversive, fearful and terrifying" [17]. Under the Law of the Republic of Azerbaijan No. 183-IIQD dated October 5, 2001, the word "terrorism" is replaced by the word "terrorist activity" in the appropriate cases of the noun. Terrorist activity in the Azerbaijani language includes the murder of people, inflicting significant damage to their health and property, or other socially dangerous consequences, menacing to cause explosion, fire or other acts (terrorist acts) that pose a threat, as well as other offences in order to violate public safety, create public panic, or influence on decision-making by public authorities or international organizations; [7]. Terrorism is primarily a form of violence and is linked to the concept of violence [9]. More specifically, terrorism is the result of physical or non-physical violence that people use in their normal lives and in some personal disputes. In the case of terrorism, people's goals are the same as those for violence. This is because violent events are events or initiatives designed to intimidate people. The main target of terrorism is not only to create a frightening disharmony within the society, but also a measure that aims to change the economic order of a state or to have a negative impact on its economy.

Although the targets of the terrorists differ, in general, their desires can be summed up under the following three goals.

- Promotion: Terrorism is one of the tools used to explain the purpose and motive to the people. The terrorists choose the cities where the damage could be more severe since they want to attract media attention.

- Political instability: Terrorists act beyond the institutional political framework to weaken the legitimacy of the existing regime to achieve their goals.

- Damage to the economy: Terrorists seek to inflict material damage in order to have pressure on the society [11].

\section{The relationship between terrorism and the tourism industry}

Tourism and terrorism conceptions have similar aspects, such as being in the international dimension, using technological advances in the field of transportation and communication in accordance with their own interests [18]. However, the environment that is completely opposite to the environment created by terrorism is required in order for the tourism industry to survive. While factors such as national and international peace, political stability and economic development are 
among the key characteristics of the formation and development of tourism movements, it is accepted that since terror and terrorism thrive by virtue of political instability, these two concepts cannot exist in the same time and environment.

Terrorism and Political instability are not concepts to be considered independently (Wieviorka 1994; Hall and O'Sullivan 1996; Lea 1996). Wieviorka (1994) used Lebanon, Italy and West Germany as examples to demonstrate how political crises could eventually end in terrorism. In fact,apart from terrorism, international, regional and civil wars, genocides, martial law, military coups and riots can also lead to political issues that imperil the security of both certain countries and thewhole region, as seen in the Middle East, the Balkans and East Africa [19]. The strong link between political instability and terrorism may clarify the reason why in some sources it is difficult to distinguish between these two concepts. Despite their dissimilar characteristics, both political instability and terrorism have atremendous impact on tourism.

Terrorist attacks are quite common in countries such as Iraq, Afghanistan, Pakistan or Sri Lanka, and most of them remain unclaimed by any terrorist groups. These areas are often avoided by tourists because of the high risk of suicidal or bomb attacks and armed robbery. In the research recently conducted by several experts it has been observed that terrorist acts mostly target the tourism consumers in the relevant country Spain, Turkey, Egypt, Tunisia, and France. (Pizam, Tarlow and Bloom, 1997, 23; Richter and Waugh, 1993, 319).These attacks are aimed at killing foreigners from different states in order to create tension between countries, generate panic among the population, and consequently deprive the respective destination of tourists. This entire complex tends to destabilize the area economically and destroy the collaboration between some countries. While the development of the tourism industry slows down in the country or region where terrorism exists, terrorism makes use of the tourism industry to achieve its goals.

There are various reasons why terrorist acts targetparticularly tourist areas and tourists. These can be enumerated as follows:

- Terrorist acts in tourist areas or urban centers cause great damage to the country's economy. After the September 11 attacks, air travel seemed to be quite risky and it affected not only American airlines but also the local economy.
- Tourists are targeted for acts of terror in order to harm the economies of countries with high income generated from tourism.

- If tourists or tourist areas are targeted, it means the state is targeted by terrorists. Therefore, any attack on tourism is considered to be directly committed against the state.

- Terrorists can easily convey the messages they want to convey, because they know that any attack on tourists and tourist destinations will have a wide echo in both written and oral media, both nationally and internationally.

- The destruction of a museum and historical sites that reflect the history, geography and identity of a country is an easy way for terrorists to capture both success and attention.

- Less security measures in the tourist areas to providemore comfort for tourists during the holidays, which tempt terrorists to target these areas.

- Foreign tourists, especially for radical religious terrorist organizations, are seen as representatives of the West and become the main target of terrorists [10].

The impact of terrorism on tourism can be illustrated by examples from different countries: The effects of terrorism and the fear of imperilment on the British show themselves particularly in vacation plans to Turkey. Half of the people said they had changed their travel plans to Turkey because of this concern. According to a survey of more than 1,200 people, more than half said they would go abroad for a holiday. 55\% said the probability of choosing Turkey as their travel destination is lower compared to previous years. Women are the most affected by the events in Turkey. $59 \%$ of women have a negative view of Turkey because of the danger [13].

The study compared data from $26 \mathrm{EU}$ countries and 13 MENA countries for the period 2002-2013. The countries involved in the study are included in the analysis. The links between terrorist acts and tourism in these countries have been explored. As a result, empirical evidence from the study suggests that Islamic countries in the Middle East and North Africa are affected by terrorist acts more than 26 countries in the European Union. Terror in MENA countries has a negative impact of tourism at rate of $0.23[8]$. 


\section{The role of the struggle against terrorism in the progression of tourist industry in Azerbaijan}

By the Decree of the President of the Republic of Azerbaijan on Intensified Combat against Crime and Reinforcement of Law and Order (adopted on August 9, 1994), the main functions of the Ministry of Internal Affairs and other state bodies are to ensure the protection of the economic and political foundations of the country, to prevent crime, bribery and corruption committed by the associations against life, health, and property rights of citizens, to carry out operational and service activities in this area andOrganized Crime Departmentwas established in the structure of the Ministry and focuses on fighting against the most dangerous form of crime.

By the Decree of the President of the Republic of Azerbaijan on Amendments at the Ministry of Internal Affairs of the Republic of Azerbaijan (adopted on June 30, 2004), Organized CrimeDepartment was upgraded and designated as the main executive body.Thepredominantfunctions of the Main Department include combating organized crime, comprising of terrorism, banditry, kidnapping and threats of extortion, illegal circulation of counterfeit money and payment documents, as well as the struggle against transnational and other forms of organized crime in compliance with the laws and regulations of the Republic of Azerbaijan and relevant regulations of the Ministry of Internal Affairs;

The structure of the Main Department includes Unit for Combating Kidnapping and Extortion crimes, Unit for Combatting Banditry and Other Dangerous Crimes, Unit for Combating Illegal Circulation of counterfeit money and payment documents, Investigation Department, Organizational-Analytical Unit and Other Operations and Procurement units [4]. Since 2015, Azerbaijan has entirely opened its doors to tourists. Since then, Azerbaijan had increased the security measures, although it is in the forefront in terms of security. This increase could prevent potential terrorist acts.

As of February 1, 2016, visa facilitation at Azerbaijani airports for residents of Qatar, Oman, Saudi Arabia, Bahrain, Kuwait, Japan, China, South Korea, Malaysia and Singapore launched. This decision was made by President Ilham Aliyev at the meeting of the Cabinet of Ministers of the Republic of Azerbaijan in the first half of 2015 to encourage tourists. At the same time, citizens from 95 countries started applying for a visa online with ASAN Visa.

There have been records of terrorist attacks being managed to be stopped in Azerbaijan all through the 2016; nevertheless, it is ambiguous if an $\mathrm{y}$ of these proactive measures have been taken again st bona fide terrorist provocations or have been inten ded to curtail the endeavors of previously nonviolent self governing theological militants.

The SSS detained eight suspected criminals through out a counterterrorism operation on 12 February.

Some of those were accused of terrorist attacksrelated charges and jailed.

The SSS reported on October 27 that its officers had carried out operations in which two persons who w ere accused of devising acts of terrorism in Azerbaij an were murdered and a third was injured. In the dec laration the SSS reported

that the men formed a trained and equipped commu nity in Azerbaijan and vowed loyalty to terror organ izations engaged in armed conflicts outside Azerbaij an.

On 16 November a judiciary in Baku sentenced seve $\mathrm{n}$ Azerbaijani residents on allegations they volunteer ed to struggle along with ISIS rebels and other terror organizations in Iraq and Syria. The jury convicted the accused from 2 to 14-year prison terms. On November 25, a alleged terrorist was murdered while on an SSS operation in Khachmaz District of Azerbaijan. Terror suspect was accused of heading a terror group participating in military conflicts and recruiting Azerbaijani people to participate in a battle elsewhere. An SSS statement stated suspects had obtained weapons and bombs unlawfully and were plotting terrorist attacks and kidnappings. SSS policemen murdered a man on December 3 whom the government blamed for transporting an explosive device and designing to engage in terrorism on the region of Azerbaijan. In a release, the SSS told the press that policemen tried to capture terror suspect nearby a shopping mall in Baku, and murdered him as he posed a hazard to the officers of the SSS. He tried to blow up the "martyr's belt" resistingly which was destroyed by a special operation team in response. This shopping mall is called Bina Shopping Center. It is one of the places visited by almost every tourist traveling to Azerbaijan. A possible terrorist attack in this shopping center could damage the image of the Azerbaijan in the world wide tourism industry. The bomb was defused while he was trying to detonate an explosive device on him. 
Terror suspect had pledged "loyalty to members of global terror organisations and illegal armed groups active in foreign disputes," according to the information received from the state. Terrorist had initially served nine years in jail for subscribingto a terror organization and restarted direct interaction with other Azerbaijani radical extremists fighting in war zones and making preparations for terrorist activities in Azerbaijan due to an SSS declaration [14]. In 2017, law enforcement and security agencies in Azerbaijan reported countered numerous suspected terror attempts, which would include:

- On 27 January, SSS policemen in Azerbaijan murd ered accused "religious extremists." The SSS claime $\mathrm{d}$ that terrorist suspect had resisted detention.

-The SSS administered a raid on February 1 and mu rdered four members of a group that the SSS stated was associated with terror organizations functioning in overseas preparing terror attacks in Azerbaijan.

- The SSS announced on August 28 that its policemen murdered a suspected criminal while attempting to apprehend him. The SSS confirmed that the terrorist had purchased weapons and bombs with funds obtained from an overseas terror organization group .

-The SSS imprisoned Azerbaijani civilians o n 27 October, on accusation of battling in Syria and Iraq [15].

In 2018 Azerbaijani laws enforcement and security $\mathrm{f}$ orces stated that so many potential terror attempts $\mathrm{w}$ ere stopped along with:

- On November 14, the SSS announced that five people were murdered and more than 60 people were detained while confronting police during operations following the July 3 assault to the former city mayor of Ganja, which is the second biggest city in Azerbaijan. Two policemen were also murdered in following protests. The government claimed the incidents were part of an "extremist plot" of the Shia, but civil rights advocates say governments took full advantage of unassociated criminal offenses to destroy and arrest religious activists.

- On November 23, the SSS announced the detention of three people accused of supporting terrorists in Syria, based on the most recent press reports.

- On December 9, Baku Court on Grave Crimes charged them of fighting for al-
Nusrah Front in Syria and sentenced them to 13 years, 9 years, and 9 years imprisonment, respectively. After the exchange of the 2019 articles in October 2020, the data has not yet been attai ned [16].

The measures taken by the state authorities against possible terrorist events have played a major role in the development of tourism. In September 2015, Azerbaijan participated in the White Housesponsored summit on "Combating Armed Extremism" organized by the UN General Assembly. In 2015, the Ministry of National Security underwent major reforms, and in midDecember, the President of Azerbaijan signed a decree on the establishment of two agencies on the basis of the Ministry of National Security - the State Security Service and the Foreign Intelligence Service.

Table1. National security expenditures

\begin{tabular}{|l|l|}
\hline Year & Expenditure \\
\hline 2015 & $121.089 .332 / 0.79 a z n-200,089332$ usd \\
\hline & \\
2016 & $108.894 .688 / 1.05 a z n-1,0370922$ usd \\
\hline & \\
2017 & $111.929 .106 / 1.70 a z n-0,6584065$ usd \\
\hline & \\
2018 & $130.358 .826 / 1.70 a z n-0,7668166$ usd \\
\hline & \\
2019 & $156.989 .306 / 1.70 a z n-0,9234665$ usd \\
\hline
\end{tabular}

The table shows Azerbaijan's security expenditures in 2015-2019. The main reason for the high expenditures in 2015 was that the dollar exchange rate was 79 azn at that time and 105 azn in 2016. If we take into account that the dollar exchange rate was 170 aznin 2017-2019, we can understand the rationale for the decline after 20152016. Another reason is that in 2015, Azerbaijan took the first big step for the development of tourism and hosted the 2015 European Games. This, in turn, led to an increase in security spending. 
Table 2. Prevented terror and tourism statistics

\begin{tabular}{|c|c|c|c|c|c|c|c|}
\hline 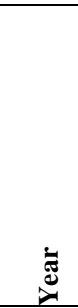 & 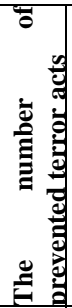 & 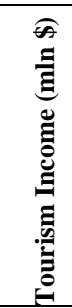 & $\%$ & 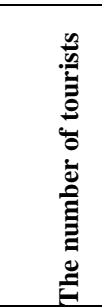 & $\%$ & 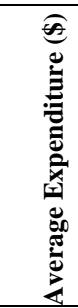 & $\%$ \\
\hline 2015 & 1 & 1673 & & 1.921 .9 & & 870 & \\
\hline 2016 & 4 & 2713 & 62,16 & 2.044 .7 & 6,39 & 1,327 & 52,42 \\
\hline 2017 & 4 & 3012 & 11,02 & 2.454 .7 & 20,05 & 1,227 & $-7,52$ \\
\hline 2018 & 3 & 2634 & $\begin{array}{l}- \\
12,55\end{array}$ & 2.605 .3 & 6,14 & 1,011 & $\begin{array}{l}- \\
17,61\end{array}$ \\
\hline 2019 & - & 2972 & 12,83 & 2.863 .5 & 9,91 & 1,038 & 2,66 \\
\hline
\end{tabular}

Source: [12]

Considering that the last terrorist attack was made in 1994, and at the same time, as a result of the development of the fight against terrorism in 2015-2019, the fact that Azerbaijan takesthe 103rd place out of 163 countries may be an evidence of Azerbaijan's progress in this area.https://reliefweb.int/sites/reliefweb.int/files/res ources/GTI-2019-A3-map-posterprint-1.pdf

Along with this decline, investments in tourism have brought income in a short time. The reason for the decline in tourism revenues in 2018 is that Azerbaijan is surrounded by countries with favorable potential for tourism. That is, we have strong competitors in the near trajectory, and it is very important to be able to compete with them. In particular, as one of the countries in the region, Georgia is a strong competitor for Azerbaijan. From this point of view, it is interesting to compare the indicators of Georgia in the tourism sector for 2018 with Azerbaijan. According to the Central Bank of Georgia, in 2018, the country's revenues from foreign tourism was $\$ 3.3$ billion. While revenues from foreign tourism decreased by about $\$ 350$ million in Azerbaijan in 2018, on the contrary, it increased by more than $\$ 500$ million in Georgia.

\section{Discussion}

Alongside the fact that the development of tourism has stepped into a new stage in our country, articles on tourism development perspectives, beach tourism, health tourism, winter tourism, gastronomy tourism, and the role of the Asian market in the tourism potential of Azerbaijan are published, of course, it is also undeniable that one of the most important factors for the development of tourism is security. Wheninvestigatingtheconcept of terroristattackandterrorism; it is observedthatterrorism has nolittlenegativeimpact on thenationaleconomyandthetourismindustry. I also think that this article is the first such study in Azerbaijan, and it really enhances the importance of this article.

\section{Conclusion}

In relation to terrorism and tourism, it is clear how serious the situation is when it comes to the damage that terror acts targeting tourism industry have on the international economy and the global tourism industry. The development of the tourism industry, which is of great importance in terms of international economy, in peace and tranquility conditions, has led the attention of terrorist organizations to the decline of tourism demand in the country due to the collapse of the country's image amidst war and political instability.The negative effects of terrorism and terrorist activities on the economies of the world countries can be clearly seen when the figures on the growth rates of countries, foreign trade revenues, export items, foreign direct investments to the countries and all other international activities are examined. Because terrorism is a phenomenon that aims to negatively affect the economies of the country while pursuing a mobbing policy on the society.

The study revealed that the increase in the number of foreign tourists visiting the country in 2015 - 2019 has had a significant impact not only on visa facilitation when the crossing to Azerbaijan since 2015 but also during those years, on preventing when unavoidable terrorist acts occurred.

It is clear from the results of the study that the simplification of the visa system as well as absence of terrorist activities in Azerbaijan for many years has led it to take the 103rd place out of 163 countries in the terrorism index. Participation in anti-terrorist summits since 2015, as well as funds allocated for the fight against terrorism in 20152019, have indirectly contributed to the development of tourism.

Unfortunately, preventing terrorist incidents is not entirely possible. However, the maximum avoidance of inevitable terrorist events will minimize the damage to the economy.

Preventive measures to minimize the risk of terrorist acts aimed at the tourism industry, may be as follows: 
- Individuals should be involved in tourism activities should receive safety training.

- Crisis and immediate action plans should be developed in tourism facilities.

- Government support to the tourism industry after the terrorist act should be provided.

- International cooperation should be made to prevent terrorism.

- A positive image in contrary to negative image creators should be formed through national and international media.

\section{References:}

[1] Acar, A. and Chetin, G. (2018) Economic Relationship Between Terrorism and Tourism, Journal of Recreation and Tourism Research 4 (Special Issue 1), 255-274

[2] Akinci, M., \& Yilmaz, O. (2015). International terrorism as a tourism crisis: Panel data analysis by country groups. Kocaeli University Journal of Social Sciences, (30), 51-76.

[3] Akinci, M., Akinci, G. Y., \& Yilmaz, Ö. (2015). The Effects Of Terrorism On Direct And Indirect Investments: How Expensive Are External AIDS?. Ankara University SBF Journal, 70 (1), 1-33.

[4] Decree of the President of the Republic of Azerbaijan dated August 9, 1994 "On Strengthening Crime, Law Enforcement and Enforcement of Laws https://mia.gov.az/index.php?/az/content/272/

[5] International Tourism Growth Continues To Outpace The Global Economy UNWTO, 2020, 2.

[6] Karagoz, H. (2016). "Terrorism's Impact on tourists and tourism income in Turkey". Istanbul Commerce University Foreign Trade Institute Working Paper Series, 19, 1-13.

[7] Legislative Collection of the Republic of Azerbaijan, 2001 year. http://www.eqanun.az/framework/3855

[8] Ozcan, C. C., \& OZMEN, İ. (2016). A Comparative Analysis of The Relation of Terror And Tourism: The Example Of The Eu And Mena. Omer Halisdemir University, Faculty of Economics and Administrative Sciences, 9 (4), 69-83.

[9] Ozerkmen, N. (2004). Terrorism, Terrorism And Radical Islamist Terror, Ankara University, Journal of Language and HistoryGeography Faculty, 44 (2), 242-265.
[10] Serchek, G. O., \& Serchek, S. (2016). The Impact of Tourism Sector Development: Terrorism. The Journal of Academic Social Science Studies, 42, 431-444.

[11] Tavares J. (2004). The Open Society Assesses Its Enemies: Shocks, Disasters And Terrorist Attacks. Journal Of Monetary Economics, 51(5), 1039-1070

[12] The State Statistical Committee of The Republic of Azerbaijan https://www.stat.gov.az/Index.php 2020

[13] Tourismdatabank.com, 2020

[14] U.S. Department Of Statecountry Reports On Terrorism https://Www.State.Gov/Reports/CountryReports-On-Terrorism-2016/ July 19, 2017

[15] U.S. Department Of Statecountry Reports On Terrorism https://Www.State.Gov/Reports/CountryReports-On-Terrorism-2017/ September 19, 2018

[16] U.S. Department Of Statecountry Reports OnTerrorism https://Www.State.Gov/Reports/CountryReports-On-Terrorism-2018 / November 1,2019

[17] Unsal, A. ve Kelesh, R. (1982), Urban And Political Violence, Ankara university, Faculty of Political Sciences Publications: 507

[18] Unur, K. (2000). Turizm - Terörizm İlişkisi ve Türkiye Örneği. Anatolia: Turizm Araştımaları Dergisi, Yıl: 11, Eylül - Aralık, ss: 169-177.

[19] Wieviorka M. (1994). The Making of Terrorism. Chicago: University of Chicago Press. 